\title{
Pengujian Anomali January Effect Terhadap Saham Pada Perusahaan Yang Terdaftar Di Jakarta Islamic Index
}

\author{
Ika Yustina Rahmawati ${ }^{1}$ Tiara Pandansari ${ }^{2}$ \\ Manajemen, Fakultas Fakultas Ekonomi dan Bisnis, Universitas Muhammadiyah Purwokerto ${ }^{1}$ \\ Akuntansi, Fakultas Fakultas Ekonomi dan Bisnis, Universitas Muhammadiyah Purwokerto ${ }^{2}$ \\ yustinaika85@gmail.com ${ }^{1}$ tiarapandansari@gmail.com ${ }^{2}$
}

\begin{abstract}
Abstrak
Tujuan dari penelitian ini adalah untuk untuk menguji perbedaan return dan abnormal return pada bulan Januari dan selain bulan Januari pada indeks JII. Sampel yang digunakan adalah saham perusahaan yang termasuk pada indeks JII, penelitian ini merupakan event study sehingga pada periode pengamatan akan melihat reaksi pada sebelum, saat, dan sesudah event. Pada penelitian ini, periode yang digunakan adalah $\mathrm{H}$ 10 (sebelum event), H0 (saat event) dan $\mathrm{H}+10$ (sesudah event). Sumber data diperoleh dari yahoo finance, sahamok.com dan IDX. Jenis data yang digunakan dalam penelitian ini adalah data sekunder, diantaranya adalah harga penutupan saham yang sudah disesuaikan (adjusted closing price) dan harga penutupan IHSG. Data berupa harga saham harian (daily stock price). Data-data tersebut kemudian dianalisis dengan menggunakan metode analisis paired sample t-test. Hasil penelitian menunjukkan bahwa jika dilihat return saham $\left(\mathrm{R}_{\mathrm{it}}\right)$ pada tahun 2014 dan 2015 menunjukkan adanya perbedaan return dan memberikan adanya signal adanya January Effect sedangkan untuk tahun 2016 hasilnya berbeda dengan tahun sebelumnya karena hasilnya tidak menunjukkan perbedaan return dan dipastikan tidak ada indikasi January effect. Untuk abnormal return (AR) untuk semua tahun penelitian $(2014,2015,2016)$ menunjukkan adanya perbedaan, yang menunjukkan adanya perbedaan AR dan memberikan signal adanya January Effect sehingga memengaruhi para pelaku pasar dalam mengambil keputusan.
\end{abstract}

Kata Kunci: return (Rit); abnormal return (AR); event study; January Effect.

\section{Examination of Anomaly January Effect On Shares in A Company Registered at The Jakarta Islamic Index}

\begin{abstract}
The purpose of this study is to examine differences in Return and abnormal returns in January and other than January in the JII index. The sample used is the company's stock included in the JII index, this research is an event study so that during the observation period will see the reaction before, during and after the event. In this study the periods used were $\mathrm{H}-10$ (before the event), $\mathrm{HO}$ (during the event) and $\mathrm{H}+10$ (after the event). Source of data obtained from yahoo finance, stockok.com and IDX. The type of data used in this study is secondary data, including the closing price of shares that have been adjusted (adjusted closing price) and the closing price of the JCI. Data in the form of daily stock price (daily stock price). The data are then analyzed by paired sample t-test. The results showed that if seen in stock returns (Rit) in 2014 and 2015 showed a difference in return and gave a signal of the January Effect while for 2016 the results were different from the previous year because the results did not show a difference in returns and confirmed there was no January effect indication. Abnormal returns (AR) for all years of research $(2014,2015,2016)$ shows the existence of differences, which indicates the existence of differences in AR and signals the existence of the January Effect that affects market participants in making decisions.
\end{abstract}

Keyword: return $\left(R_{i t}\right)$; abnormal return (AR); event study; January Effect. 


\section{PENDAHULUAN}

Bagi para peneliti di bidang keuangan atau para pelaku di pasar seringkali mengamati sebuah peristiwa (event) untuk melihat pengaruh terhadap kondisi lingkungan suatu perusahaan, dalam hal ini sangat erat kaitannya dengan pergerakan saham-saham di pasar modal. Pasar modal merupakan salah satu instrumen yang banyak dijumpai pada banyak Negara karena pasar modal menjalankan fungsi ekonomi dan keuangan (Husnan, 2009). Dari fungsi tersebut, pasar modal sangat besar dipengaruhi oleh berbagai peristiwa yang memiliki kandungan informasi bagi investor sehingga semakin penting peran pasar modal dalam suatu negara, maka semakin sensitif terhadap berbagai peristiwa yang terjadi di lingkungannya (Suryawijaya dan Setiawan, 1998 dalam Zaqi, 2006)

Peristiwa yang dimaksud adalah peristiwa yang terjadi dalam internal perusahaan dan eksternal perusahaan. Peristiwa internal perusahaan biasanya terjadi akibat adanya kebijakan yang dibuat oleh pimpinan, misalnya kebijakan dividen, kebijakan ekspansi, kebijakan merger atau akuisisi, kebijakan mengenai pendanaan dan masih banyak kebijakan internal perusahaan yang akan membawa signal atau informasi bagi para investor. Penelitian yang mengacu pada peristiwa (event study) pertama dilakukan oleh Fama, et al. (1969) dalam bidang ekonomi keuangan. Event study adalah tes bersama efisiensi pasar dan model tingkat pengembalian yang diharapkan yang digunakan dalam memperkirakan abnormal return. Inovasi desain penelitian dari Fama, et al. memungkinkan peneliti untuk menyelaraskan sampel perusahaan dalam suatu waktu (event time) dan kemudian memeriksa kinerja harga saham mereka sebelum, selama, dan setelah peristiwa ekonomi seperti pemecahan saham (Fama, et al. 1969).Walaupun konsep pasar efisien ini masih menjadi perdebatan di kalangan peneliti keuangan tetapi banyak studi empiris yang telah dilakukan dan mendukung konsep tersebut. Namun, pada satu sisi timbul pula anomali pasar yang merupakan penyimpangan dari konsep pasar efisien. Bentuk penyimpangan tersebut diantaranya adalah January Effect, size effect, Monday effect, Rogalsky effect, day of week effect dan lain sebagainya.

Beberapa penelitian sebelumnya yang telah melakukan penelitian untuk anomali di atas adalah Sari dan Fitriyani (2013) yang memberikan Bukti bahwa dengan menggunakan tiga proksi penelitian yaitu return saham, abnormal return dan trading volume activity, maka dua proksi yaitu return saham dan abnormal return dapat menunjukkan adanya indikasi January Effect sedangkan dari trading volume activity tidak terlihat adanya January Effect, untuk saham pada perusahaan indeks LQ-45. Hasil studi empiris lainnya yang mendukung adanya January Effect adalah dari penelitiannya Subekti (2005) dalam Aprilia dkk (2013) menunjukkan bahwa para pemodal di pasar bursa cenderung memiliki reaksi yang berlebihan pada lima hari pada awal bulan Januari.

Perbedaan hasil penelitian menjadi suatu ketertarikan sendiri bagi para peneliti yang nantinya akan dijadikan referensi untuk melakukan perbandingan pada penelitian selanjutnya. Dalam konsep anomali pasar ini juga terbukti ada sebagian perbedaan dalam hasil contohnya hasil penelitian yang dilakukan oleh Aprilia dkk (2013) dengan menggunakan sampel pada saham perusahaan di sektor manufaktur menunjukkan bahwa tidak ada anomaly January Effect dan tidak ada perbedaan yang siginifikan antara rata-rata abnormal return saham pada sebelum dan sesudah January Effect. Selaras dengan hasil penelitian dari Hartini dan Fitriani (2013) memberikan Bukti bahwa tidak ada penyimpangan January Effect untuk saham-saham perusahaan pada sector otomotif. Dari Pratomo (2007) hasil penelitiannya menunjukkan hal yang sama yaitu tidak ada anomali January Effect.

Rangkaian penelitian di atas memberikan hasil yang beragam dan memiliki tingkat sensitifitas informasi yang beragam pula untuk investor. Sehingga dari beragamnya hasil penelitian tersebut, analisis anomali yang terjadi di pasar modal masih menjadi sesuatu yang menarik untuk dilakukan. Fokus penelitian ini adalah pada anomali January Effect karena hal ini sangat berkaitan erat dengan laporan keuangan, di mana January Effect terjadi akibat perusahaan-perusahaan yang melakukan perbaikan laporan keuangan pada akhir tahun. Pada bulan Desember, saham-saham yang kurang baik di lepas sehingga yang tersaji di laporan keuangan adalah nilai investasi yang baik. Berdasarkan latar belakang tersebut dan ketidakkonsistenan hasil penelitian terdahul,u maka permasalahan pokok yang akan diangkat dalam penelitian ini adalah pengujian anomali January Effect terhadap saham-saham pada perusahaan yang terdaftar di Jakarta Islamic Index. Berdasarkan latar belakang tersebut, maka tujuan penelitian ini adalah untuk menguji adanya perbedaan return saham pada bulan Januari dan selain bulan Januari dan abnormal return saham pada bulan Januari dan selain bulan Januari pada indeks JII 


\section{METODE PENELITIAN}

Populasi dalam penelitian ini adalah seluruh perusahaan yang terdaftar di Bursa Efek Indonesia periode tahun 2014-2016. Kriteria pemilihan sampel menggunakan metode purposive sampling, yaitu teknik penelitian sampel dengan pertimbangan tertentu. Sehingga perusahaan yang dipilih menjadi sampel penelitian yang memenuhi kriteria sebagai berikut:

1. Perusahaan-perusahaan yang terdaftar dalam Jakarta Islamic Index(JII), dengan periode penelitian pada tahun 2014 - 2016.

2. Saham perusahaan tercatat secara terus menerus selama periode pengamatan. Karena jika tidak berkesinambungan maka akan menimbulkan hasil yang bias.

3. Memiliki data transaksi yang lengkap selama periode pengamatan.

Data yang digunakan dalam penelitian ini merupakan jenis data sekunder yang sudah tersedia dan diperoleh dari website www.idx.go.id, IDX fact book, www.financeyahoo.com. Data sekunder yang digunakan diantaranya adalah:

1. Daftar perusahaan yang tergabung dalam Jakarta Islamic Index pada tahun 2014-2016.

2. Data penutupan harga saham yang sudah disesuaikan (adjusted closing price) selama periode penelitian pada tahun 2014-2016.

3. Indeks Harga Saham Gabungan (IHSG) selama periode penelitian pada tahun 2014-2016.

Tabel 1

Definisi Operasional Variabel

\begin{tabular}{|l|l|l|}
\hline \multicolumn{1}{|c|}{ Variabel } & \multicolumn{1}{|c|}{ Definisi } & \multicolumn{1}{|c|}{ Pengukuran } \\
\hline Return saham & $\begin{array}{l}\text { Return saham yang diperoleh dengan menggunkan } \\
\text { logaritma natural (ln) yaitu membagi harga penutupan } \\
\text { akhir bulan dengan harga penutupan akhir bulan } \\
\text { sebelumnya. }\end{array}$ & $R_{i t}=\ln \left(P_{i} / P_{i t-1}\right)$ \\
\hline Return pasar & $\begin{array}{l}\text { Return pasar yang digunakan adalah IHSG. Untuk } \\
\text { perhitungannya menggunakan logaritma natural (ln) } \\
\text { yaitu dengan menghitung IHSG bulan t dibagi dengan } \\
\text { IHSG pada bulan t-1 (bulan sebelumnya) }\end{array}$ & $R_{m t}=\ln \left(I H S G_{t} / I H S G_{t-1}\right)$ \\
\hline $\begin{array}{l}\text { Abnormal } \text { return } \\
(A R)\end{array}$ & $\begin{array}{l}\text { Abnormal return (AR) saham dihitung menggunkan } \\
\text { metode market adjusted model dengan mencari selisih } \\
\text { return bulanan masing-masing sampel dengan return } \\
\text { indeks pasar yang diwakili oleh return IHSG bulanan } \\
\text { (Jogiyanto, 2003) }\end{array}$ & $A R_{i t}=R_{i t}-R_{m t}$ \\
\hline
\end{tabular}

Sumber: Hartono (2014)

Adapun teknik analisis data dalam peneilitian ini dengan menggunakan event windows.

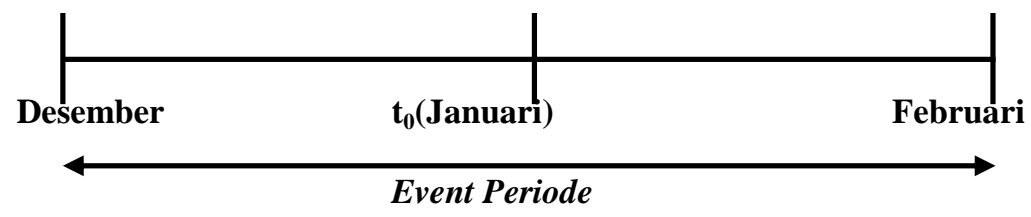

Gambar 1. Event Windows

Dari event windows tersebut maka langkah-langkah yang harus dilakukan adalah:

1. Menentukan sampel perusahaan pada index JII sesuai dengan kriteria.

2. Menentukan waktu penelitian (event date), $\mathrm{t}-31$ yaitu satu bulan sebelum bulan Januari. $\mathrm{t}_{0}$ yaitu saat bulan Januari dan $\mathrm{t}+30$ ) yaitu setelah bulan Januari.

3. Mencatat harga penutupan saham harian sesuai sampel perusahaan yang sudah ditentukan pada even periode.

4. Mencatat IHSG pada even periode.

5. Melakukan perhitungan return saham harian $\left(\mathrm{R}_{\mathrm{it}}\right)$ yang diambil dari harga saham penutupan (closing price), dengan menggunakan rumus berikut ini: 
6. $\mathrm{R}_{\mathrm{it}}=\ln \left(\mathrm{P}_{\mathrm{it}} / \mathrm{P}_{\mathrm{it}}-1\right)$

di mana:

$\mathrm{R}_{\mathrm{it}} \quad$ : Return saham ke i untuk bulan ke-t

$\ln \quad$ : Logaritma natural

$\mathrm{P}_{\text {it }} \quad$ : Harga penutupan untuk saham i pada bulan ke-t.

$\mathrm{P}_{\mathrm{it}^{-1} 1}$ : Harga penutupan untuk saham i pada bulan sebelumnya.

7. Melakukan perhitungan return pasar bulanan $\left(\mathrm{R}_{\mathrm{mt}}\right)$. Dengan menggunakan rumus di bawah ini:

$\mathrm{Rmt}=\ln \left(\mathrm{IHSG}_{\mathrm{t}} / \mathrm{IHSG}_{\mathrm{t}-1}\right)$

di mana:

$\mathrm{R}_{\mathrm{mt}} \quad$ : Return market pada bulan ke-t

ln : Logaritma natural.

IHSG $_{\mathrm{t}} \quad$ : Index Harga Saham Gabungan (IHSG) pada bulan ke-t

IHSG $_{\mathrm{t}-1} \quad$ : Index Harga Saham Gabungan (IHSG) pada bulan sebelumnya

8. Menghitung Abnormal Return $\left(\mathrm{AR}_{\mathrm{it}}\right)$ dengan menggunakan metode market adjusted model, dengan rumus sebagai berikut:

$\mathrm{AR}_{\mathrm{it}}=\mathrm{R}_{\mathrm{it}}-\mathrm{R}_{\mathrm{mt}}$

di mana:

$\mathrm{AR}_{\mathrm{it}}$ : Abnormal Return saham i pada bulan ke-t

Rit : Return saham i pada bulan ke-t.

$\mathrm{R}_{\mathrm{mt}} \quad$ : Return market (return pasar) pada bulan ke-t.

9. Data dianalisis dengan menggunakan uji beda paired sample t-test, di mana sebelum dilakukan analisis data akan dilakukan uji normalitas terlebih dahulu, dengan bantuan program excel 2013 dan software SPSS 21.

10. Menarik kesimpulan

\section{Pengujian Hipotesis}

Untuk mengetahui tingkat signifikansi dari hipotesis yang dibentuk dalam penelitian ini menggunakan uji bedapPaired sample t-test atau uji beda rata-rata dua sampel yang berpasangan dengan taraf signifikansi yang digunakan adalah 5\% (0.05). Prasyarat yang harus dipenuhi dalam uji beda paired sample t-test adalah jika nilai signifikansit hitung > 0,05 maka Ho ditolak artinya berpengaruh secara signifikan dan jika nilai signifikansi t hitung $<0.05$ maka Ho diterima yang artinya tidak ada pengaruh yang signifikan. Hipotesis yang dibentuk dalam penelitian ini adalah:

$\mathbf{H}_{1}$ : Menguji perbedaan return saham di bulan Januari dan selain bulan Januari pada indeks JII, sehingga untuk mengetahui perbedaan return tersebut maka terbentuklah $\mathrm{H}_{0}$ dan $\mathrm{Ha}$ berikut ini:

$\mathrm{H}_{0}$ : Tidak ada perbedaan return saham di bulan Januari dan selain bulan Januari pada indeks JII

$\mathrm{H}_{\mathrm{a}}$ : Ada perbedaan return saham di bulan Januari dan selain bulan Januari pada indeks JII

$\mathbf{H}_{2}$ : Menguji perbedaan abnormal return saham di bulan Januari dan selain bulan Januari pada indeks JII, sehingga untuk mengetahui perbedaan abnormal return tersebut maka terbentuklah $\mathrm{H}_{0}$ dan $\mathrm{Ha}$ berikut ini:

$\mathrm{H}_{0}$ : Tidak ada perbedaan abnormal return saham di bulan Januari dan selain bulan Januari pada indeks JII

$\mathrm{H}_{\mathrm{a}}$ : Ada perbedaan abnormal return saham di bulan Januari dan selain bulan Januari pada indeks JII

\section{HASIL DAN PEMBAHASAN}

Sampel yang digunakan dalam penelitian ini adalah perusahaan yang termasuk pada indeks saham JII (Jakarta Islamic Indeks) yang terdaftar di Bursa Efek Indonesia (BEI) dengan jumlah observasi sebanyak 30 perusahaan, harga saham yang digunakan merupakan data saham harian pada bulan Desember 2013, 2014, 2015 dan Januari 2014, 2015 dan 2016 dengan range waktu yang digunakan yaitu (H-10) harga saham harian 10 hari sebelum kejadian, (H0) harga saham sewaktu peristiwa terjadi dan $(\mathrm{H}+10)$ harga saham setelah January Effect.

Statistik deskriptif yang dijelaskan dalam penelitian ini memberikan gambaran mengenai data yang digunakan, penelitian ini menggunakan data return $\left(\mathrm{R}_{\mathrm{it}}\right)$ harian dan abnormal return (AR). Gambaran data tersebut yaitu mean, standar deviasi dan jumlah observasi penelitian. 
Tabel 2

Statistik Deskriptif Return (Rit)

\begin{tabular}{|c|c|c|c|c|c|c|c|}
\hline \multicolumn{3}{|c|}{ Data Return (Rit) } & \multicolumn{2}{|c|}{ Data Return (Rit) } & \multicolumn{3}{|c|}{ Data Return (Rit) } \\
\hline & 013-201 & & 2014 & & & 15-2016 & \\
\hline Kriteria & Mean & St.Dev & Mean & St.Dev & Mean & St.Dev & Obs \\
\hline $\mathrm{H}-10$ & -.0162 & .02041 & -.0260 & .02377 & 101.2166 & 385.80163 & 30 \\
\hline $\mathrm{H}-9$ & .0137 & .01963 & .0034 & .02193 & 101.2310 & 385.47168 & 30 \\
\hline $\mathrm{H}-8$ & .0093 & .01598 & .0157 & .01749 & 104.6453 & 398.62368 & 30 \\
\hline $\mathrm{H}-7$ & .0030 & .01601 & .0061 & .02580 & 104.3208 & 397.84045 & 30 \\
\hline H-6 & -.0089 & .02992 & -.0076 & .01759 & 105.7930 & 403.42062 & 30 \\
\hline $\mathrm{H}-5$ & -.0072 & .02215 & .0036 & .01141 & 107.7896 & 410.47045 & 30 \\
\hline $\mathrm{H}-4$ & .0067 & .01572 & .0050 & .01721 & 108.9431 & 414.90406 & 30 \\
\hline $\mathrm{H}-3$ & -.0004 & .01262 & .0059 & .01498 & 108.8061 & 414.04180 & 30 \\
\hline $\mathrm{H}-2$ & .0093 & .01298 & .0035 & .01395 & 109.4545 & 416.55512 & 30 \\
\hline $\mathrm{H}-1$ & .0159 & .02751 & .0112 & .02597 & 118.2470 & 451.48013 & 30 \\
\hline HO & -.0186 & .01696 & -.0052 & .01367 & 110.8979 & 422.79704 & 30 \\
\hline $\mathrm{H}+1$ & -.0245 & .02630 & -.0118 & .01448 & 112.2092 & 428.09610 & 30 \\
\hline $\mathrm{H}+2$ & -.0170 & .01923 & .0108 & .01533 & 111.5305 & 425.23272 & 30 \\
\hline $\mathrm{H}+3$ & .0159 & .02206 & .0053 & .02164 & 110.4090 & 420.70296 & 30 \\
\hline $\mathrm{H}+4$ & -.0027 & .01827 & .0052 & .01906 & 110.7256 & 421.76318 & 30 \\
\hline $\mathrm{H}+5$ & .0175 & .03308 & -.0041 & .02164 & 107.9550 & 411.15592 & 30 \\
\hline $\mathrm{H}+6$ & .0278 & .03839 & .0099 & .03486 & 109.4390 & 416.68327 & 30 \\
\hline $\mathrm{H}+7$ & .0087 & .02442 & -.0185 & .02183 & 108.7569 & 414.30728 & 30 \\
\hline $\mathrm{H}+8$ & -.0023 & .02043 & .0057 & .01447 & 109.8944 & 419.20656 & 30 \\
\hline $\mathrm{H}+9$ & .0039 & .01574 & -.0143 & .02663 & 110.0537 & 419.87131 & 30 \\
\hline $\mathrm{H}+10$ & .0076 & .02030 & -.0003 & .02335 & 109.3973 & 417.93368 & 30 \\
\hline
\end{tabular}

Sumber: data diolah, 2018

Tabel 2 memberikan gambaran bahwa dengan menggunakan data return (Rit), tingkat rata-rata pengembalian atau return $\left(\mathrm{R}_{\mathrm{it}}\right)$ tertinggi (periode Desember 2013 - Januari 2014) pada sebelum terjadinya peristiwa ada pada H-1 yaitu 0.0159 dengan tingkat risiko sebesar 0.02751. Saat terjadinya peristiwa (H0) tingkat rata-rata pengembalian menurun jauh dibandingkan satu hari sebelum kejadian yaitu -0.0186 tetapi walaupun lima hari setelah kejadian nilai masih menurun, saat $\mathrm{H}+6$ harga saham mulai memperlihatkan pergerakan yang cukup baik karena nilai rata-rata pengembalian menjadi positif yaitu 0.0278 dengan tingkat risiko sebesar 0.039 .

Tingkat rata-rata pengembalian atau return $\left(\mathrm{R}_{\mathrm{it}}\right)$ tertinggi (periode Desember 2014 - Januari 2015) pada sebelum terjadinya peristiwa ada pada H-8 yaitu 0.0157 dengan tingkat risiko sebesar 0.017. Saat terjadinya peristiwa (H0) tingkat rata-rata pengembalian menurun jauh dibandingkan satu hari sebelum kejadian yaitu -0.0052 tetapi berselang satu hari seteah kejadian nilainya mengalami penurunan, dan saat $\mathrm{H}+1$ harga saham mulai memperlihatkan pergerakan yang cukup baik karena nilai rata-rata pengembalian menjadi positif yaitu 0.0108 dengan tingkat risiko sebesar 0.015 , tetapi setelah itu rata-rata tingkat pengembalian mengalami nilai yang fluktuatif. Periode Desember 2015-Januari 2016, Tingkat rata-rata pengembalian/return $\left(\mathrm{R}_{\mathrm{it}}\right)$ tertinggi pada sebelum terjadinya peristiwa ada pada $\mathrm{H}-1$ yaitu 118,2 dengan tingkat risiko sebesar 451,4. Saat terjadinya peristiwa (H0) tingkat rata-rata pengembalian menurun dibandingkan satu hari sebelum kejadian yaitu 110,9 tetapi berselang satu hari seteah kejadian $(\mathrm{H}+1)$ nilainya mengalami kenaikan dengan nilai yaitu 112,2 dengan tingkat risiko sebesar 428,1 tetapi setelah itu rata-rata tingkat pengembalian mengalami nilai yang positif. 
Tabel 3

Statistik Deskriptif Abnormal Return (AR)

\begin{tabular}{|c|c|c|c|c|c|c|c|}
\hline \multicolumn{3}{|c|}{ Data Abnormal Return (AR) } & \multicolumn{2}{|c|}{ Data Abnormal Return (AR) } & \multicolumn{3}{|c|}{ Data Abnormal Return (AR) } \\
\hline \multicolumn{3}{|c|}{ 2013-2014 } & \multicolumn{2}{|c|}{ 2014-2015 } & \multicolumn{3}{|c|}{$2015-2016$} \\
\hline Kriteria & Mean & St.Dev & Mean & St.Dev & Mean & St.Dev & Obs \\
\hline $\mathrm{H}-10$ & .0044 & .02041 & .0097 & .02377 & -.0019 & .02057 & 30 \\
\hline $\mathrm{H}-9$ & -.0001 & .01963 & -.0014 & .02193 & -.0048 & .01688 & 30 \\
\hline $\mathrm{H}-8$ & -.0060 & .01598 & -.0004 & .01749 & -.0015 & .02619 & 30 \\
\hline $\mathrm{H}-7$ & .0054 & .01601 & .0000 & .02580 & -.0020 & .02172 & 30 \\
\hline H-6 & .0003 & .02992 & .0039 & .01759 & .0070 & .02199 & 30 \\
\hline $\mathrm{H}-5$ & .0058 & .02215 & -.0010 & .01141 & -.0023 & .02008 & 30 \\
\hline H-4 & -.0035 & .01572 & .0004 & .01721 & -.0016 & .02206 & 30 \\
\hline H-3 & .0028 & .01262 & -.0037 & .01498 & -.0092 & .02395 & 30 \\
\hline H-2 & .0051 & .01298 & .0058 & .01395 & -.0070 & .03713 & 30 \\
\hline H-1 & -.0036 & .02751 & -.0082 & .02597 & .0100 & .02577 & 30 \\
\hline HO & .0024 & .01696 & .0008 & .01367 & -.0022 & .02486 & 30 \\
\hline $\mathrm{H}+1$ & .0115 & .02630 & .0020 & .01448 & -.0031 & .02750 & 30 \\
\hline $\mathrm{H}+2$ & .0105 & .01923 & -.0035 & .01533 & .0021 & .02089 & 30 \\
\hline $\mathrm{H}+3$ & -.0100 & .02206 & -.0043 & .02164 & -.0011 & .01685 & 30 \\
\hline $\mathrm{H}+4$ & .0028 & .01827 & -.0042 & .01906 & .0012 & .01621 & 30 \\
\hline $\mathrm{H}+5$ & -.0048 & .03308 & -.0014 & .02164 & .0022 & .01865 & 30 \\
\hline $\mathrm{H}+6$ & .0037 & .03839 & -.0049 & .03486 & -.0003 & .01800 & 30 \\
\hline $\mathrm{H}+7$ & .0028 & .02442 & .0079 & .02183 & .0054 & .01935 & 30 \\
\hline $\mathrm{H}+8$ & -.0043 & .02043 & -.0001 & .01447 & .0062 & .01394 & 30 \\
\hline $\mathrm{H}+9$ & -.0040 & .01574 & .0065 & .02663 & -.0011 & .02031 & 30 \\
\hline $\mathrm{H}+10$ & -.0032 & .02030 & .0011 & .02335 & -.0055 & .01642 & 30 \\
\hline
\end{tabular}

Sumber: data diolah, 2018

Tabel 3 untuk abnormal return periode Desember 2013-Januari 2014 memberikan gambaran bahwa dengan menggunakan data abnormal return $(A R)$, tingkat rata-rata pengembalian tertinggi pada sebelum terjadinya peristiwa ada pada H-5 yaitu 0.058 dengan tingkat risiko sebesar 0.0022 . Saat terjadinya peristiwa (H0) tingkat rata-rata pengembalian menurun menjadi 0.024 , tetapi pada $\mathrm{H}+1$ nilai rata-rata pengembalian naik menjadi 0,0115 dan di $\mathrm{H}+2$ sampai $\mathrm{H}+10$ nilainya terus mengalami penurunan. Nilai rata-rata pengembalian tertinggi pada periode Desember 2014-Januari 2015, sebelum peristiwa ada pada H-10 dan tingkat pengembalian setelah peristiwa ada ada $\mathrm{H}+7$ sedangkan rata pengembalian tertinggi pada periode Desember 2015-Januari 2016, sebelum peristiwa ada pada H-1 dan tingkat pengembalian setelah peristiwa ada ada $\mathrm{H}+8$.

\section{Pengujian Hipotesis}

Tahap pengujian $\mathrm{H}_{1}$ adalah dengan menggunakan paired sample t-test, di mana data yang digunakan adalah return $\left(\mathrm{R}_{\mathrm{it}}\right)$ yang akan dibandingkan antara $\mathrm{R}_{\mathrm{it}}$ sebelum bulan Januari (Desember 2014) dengan $\mathrm{R}_{\mathrm{it}}$ saat awal Januari (2 Januari 2014), Rit saat awal Januari (2 Januari 2014) dengan (H+1 s/d H+10) bulan Januari dan hasil analisis tersebut akan disajikan dalam tabel 4.

Tabel 4

Pengujian Rit sebelum-Rit saat January Effect dan Pengujian Rit saat-Rit sesudah January Effect

\begin{tabular}{|c|c|c|c|r|r|r|}
\hline Kriteria & \multicolumn{2}{|c|}{ Rit 2013-2014 } & \multicolumn{2}{c|}{ Rit 2014-2015 } & \multicolumn{2}{c|}{ Rit 2014-2016 } \\
\hline & t-Hit & \multicolumn{1}{c|}{ Sig } & t-Hit & \multicolumn{1}{c|}{ Sig } & t-Hit & \multicolumn{1}{c|}{ Sig } \\
\hline H-10 dan H0 & 0.689 & 0.496 & -4.209 & $\mathbf{0 . 0 0 0} * * *$ & -1.433 & .163 \\
\hline H-9 dan H0 & 6.754 & $\mathbf{0 . 0 0 0} * * *$ & 1.868 & 0.072 & -1.380 & .178 \\
\hline H-8 dan H0 & 6.048 & $\mathbf{0 . 0 0 0} * * *$ & 5.840 & $\mathbf{0 . 0 0 0 * * *}$ & -1.328 & .194 \\
\hline H-7 dan H0 & 5.162 & $\mathbf{0 . 0 0 0} * * *$ & 2.265 & $\mathbf{0 . 0 3 1 * *}$ & -1.440 & .161 \\
\hline
\end{tabular}




\begin{tabular}{|c|c|c|c|c|c|c|}
\hline \multirow[t]{2}{*}{ Kriteria } & \multicolumn{2}{|c|}{ Rit 2013-2014 } & \multicolumn{2}{|c|}{ Rit 2014-2015 } & \multicolumn{2}{|c|}{ Rit 2014-2016 } \\
\hline & t-Hit & Sig & t-Hit & Sig & t-Hit & Sig \\
\hline $\mathrm{H}-6$ dan $\mathrm{H} 0$ & 1.544 & 0.134 & -.493 & 0.626 & -1.442 & .160 \\
\hline H-5 dan $\mathrm{H} 0$ & 2.346 & $0.026 * *$ & 2.637 & $0.013 * *$ & -1.059 & .298 \\
\hline $\mathrm{H}-4$ dan $\mathrm{H} 0$ & 5.222 & 0.000*** & 2.221 & $0.034 * *$ & -.916 & .367 \\
\hline $\mathrm{H}-3$ dan $\mathrm{H} 0$ & 5.684 & 0.000*** & 2.885 & $0.007 * *$ & -.478 & .636 \\
\hline $\mathrm{H}-2$ dan $\mathrm{H} 0$ & 6.175 & $0.000 * * *$ & 2.756 & $0.010 * *$ & -.381 & .706 \\
\hline $\mathrm{H}-1$ dan $\mathrm{H} 0$ & 8.602 & $\mathbf{0 . 0 0 0} * * *$ & 3.508 & $0.001 * * *$ & 1.358 & .185 \\
\hline H0 dan $\mathrm{H} 1$ & 1.536 & 0.135 & 1.889 & 0.069 & -1.005 & .323 \\
\hline $\mathrm{H} 0$ dan $\mathrm{H} 2$ & -.412 & 0.683 & -4.158 & 0.000*** & -1.220 & .232 \\
\hline $\mathrm{H} 0$ dan $\mathrm{H} 3$ & -5.902 & $0.000 * * *$ & -2.664 & $0.012 * *$ & .549 & .587 \\
\hline H0 dan H4 & -4.077 & $0.000 * * *$ & -2.136 & $0.041 * *$ & .097 & .923 \\
\hline H0 dan H5 & -6.208 & $0.000 * * *$ & -.231 & 0.819 & 1.123 & .271 \\
\hline H0 dan H6 & -6.084 & $0.000 * * *$ & -2.138 & $0.041 * *$ & .594 & .557 \\
\hline H0 dan $\mathrm{H} 7$ & -4.524 & $0.000 * * *$ & 2.879 & $0.007 * * *$ & 1.010 & .321 \\
\hline $\mathrm{H} 0$ dan $\mathrm{H} 8$ & -3.016 & $0.005 * * *$ & -3.069 & $0.005 * * *$ & 1.198 & .241 \\
\hline H0 dan H9 & -5.607 & $0.000 * * *$ & 1.719 & $0.096 *$ & 1.020 & .316 \\
\hline $\mathrm{H} 0$ dan $\mathrm{H} 10$ & -5.042 & $0.000 * * *$ & -.955 & 0.347 & .661 & .514 \\
\hline $\begin{array}{l}* \text { tingkat signif } \\
* * \text { tingkat signi } \\
* * * \text { tingkat sig }\end{array}$ & $\begin{array}{l}0 \% \\
5 \% \\
\text { si } 1 \%\end{array}$ & & & & & \\
\hline
\end{tabular}

Sumber: data diolah, 2016

Tabel 4 memberikan gambaran bahwa dari tingkat pengembalian (return) pada bulan Desember tahun 2013, 2014 dan 2015 (sebelum January Effect) dengan kejadan pada H0 (2 Januari) hasilnya adalah pada H-10 dan H-6 tidak signifikan sedangkan pada H-9 s/d H-7 dan H-4 s/d H-1 menunjukkan hasil yang signifikan artinya sudah ada indikasi bahwa efek bulan Januari mulai terlihat kuat menjelang awal tahun. Sedangkan periode tingkat pengembalian pada saat awal Januari (H0) dengan periode sesudah tanggal 2 Januari (H1 s/d H10) menunjukkan hasil bahwa pada saat dua hari setelah H0 nilainya tidak signifikan sedangkan pada H3 nilai signifikansi ada pada level yang sangat tinggi di angka 0.0000 , dapat disimpulkan bahwa pada periode 2013-2014 menunjukkan terjadinya January effect.

Periode selanjutnya pada akhir bulan desember 2014 dengan permulaan Januari 2015 indikasi munculnya January effect terlihat jelas karena hanya pada H-9 dan H-6 yang nilainya menunjukkan tidak signifikan sedangkan selanjutnya setelah H0 sebagian besar nilai signifikan kecuali pada H1, H5 dan H10. Sehingga perbedaan return diluar bulan Januari memberikan kesimpulan pada periode 2014 dan 2015 terjadi January effect artinya H0 ditolak karena di tahun 2014 dan 2015 terdapat perbedaan return yang berdampak pada terjadinya January Effect. Sedangkan pada Periode akhir penelitian di tahun 2015-2016 tidak menunjukkan adanya Januari effect baik pada peridoe sebelum Januari maupun setelah bulan Januari, hal ini dibuktikan dengan nilai yang tidak signifikan baik sebelum bulan Januari maupun setelah lewat awal Januari, sehingga bisa disimpulkan untuk tahun 2016 tidak ada perbedaan return untuk bulan selain Januari.

Pada pengujian $\mathrm{H}_{2}$, tidak jauh berbeda dengan analisis di hipotesis pertama, yang membedakan adalah data AR yang akan diuji yaitu AR pada sebelum Januari dan saat awal Janauri, AR saat awal Januari dan sesudah awal Januari. Hasil analisis tersebut akan disajikan dalam tabel 5. 
Tabel 5

Pengujian AR sebelum dan AR saat January Effect ; Pengujian AR saat dan AR setelah January Effect

\begin{tabular}{|c|c|c|c|c|c|c|}
\hline \multirow[t]{2}{*}{ Kriteria } & \multicolumn{2}{|c|}{ AR 2013-2014 } & \multicolumn{2}{|c|}{ AR 2014-2015 } & \multicolumn{2}{|c|}{ AR 2014-2016 } \\
\hline & t-Hit & Sig & t-Hit & Sig & t-Hit & Sig \\
\hline $\mathrm{H}-10$ dan $\mathrm{H} 0$ & 0.574 & 0.571 & 1.800 & 0.082* & 0.048 & 0.962 \\
\hline H-9 dan H0 & -0.532 & 0.599 & -0.498 & 0.622 & -0.469 & 0.642 \\
\hline $\mathrm{H}-8$ dan $\mathrm{H} 0$ & -1.817 & 0.080* & -0.343 & 0.734 & 0.092 & 0.927 \\
\hline $\mathrm{H}-7$ dan $\mathrm{H} 0$ & 0.728 & 0.473 & -0.169 & 0.867 & 0.037 & 0.971 \\
\hline H-6 dan H0 & -0.339 & 0.737 & 0.633 & 0.532 & 1.458 & 0.156 \\
\hline H-5 dan $\mathrm{H} 0$ & 0.706 & 0.486 & -0.557 & 0.582 & -0.010 & 0.992 \\
\hline H-4 dan H0 & -1.224 & 0.231 & -0.095 & 0.925 & 0.127 & 0.899 \\
\hline $\mathrm{H}-3$ dan $\mathrm{H} 0$ & 0.127 & 0.900 & -1.184 & 0.246 & -0.972 & 0.339 \\
\hline $\mathrm{H}-2$ dan $\mathrm{H} 0$ & 0.599 & 0.554 & 1.572 & 0.127 & -0.513 & 0.612 \\
\hline $\mathrm{H}-1$ dan $\mathrm{H} 0$ & -1.483 & 0.149 & -1.931 & 0.063* & 1.787 & 0.084* \\
\hline H0 dan H1 & -2.383 & $0.024 * *$ & -0.328 & 0.745 & 0.128 & 0.899 \\
\hline $\mathrm{H} 0$ dan $\mathrm{H} 2$ & -2.055 & $0.049 * *$ & 1.119 & 0.272 & -0.740 & 0.465 \\
\hline $\mathrm{H} 0$ dan $\mathrm{H} 3$ & 2.120 & $0.043 * *$ & 1.322 & 0.196 & -0.212 & 0.833 \\
\hline H0 dan H4 & -0.105 & 0.917 & 1.047 & 0.304 & -0.727 & 0.473 \\
\hline H0 dan H5 & 1.240 & 0.225 & 0.482 & 0.634 & -0.915 & 0.368 \\
\hline H0 dan H6 & -0.165 & 0.870 & 0.804 & 0.428 & -0.363 & 0.720 \\
\hline H0 dan H7 & -0.072 & 0.943 & -1.535 & 0.136 & -1.908 & $0.066 *$ \\
\hline H0 dan H8 & 1.233 & 0.227 & 0.263 & 0.795 & -1.789 & 0.084* \\
\hline H0 dan H9 & 1.589 & 0.123 & -1.065 & 0.296 & -0.190 & 0.851 \\
\hline H0 dan H10 & 1.081 & 0.289 & -.046 & 0.964 & 0.649 & 0.521 \\
\hline $\begin{array}{l}* \text { tingkat signifi } \\
* * \text { tingkat signi } \\
* * * \text { tingkat sig }\end{array}$ & $1 \%$ & & & & & \\
\hline
\end{tabular}

Sumber: data diolah, 2016

Pengujian $\mathrm{H}_{2}$ yang tersaji pada tabel 5 memberikan gambaran yang berbeda dari pengujian $\mathrm{H}_{1}$, karena jika $\mathrm{H}_{1}$ memberikan dampak secara signifikan tetapi setelah dibandingkan antara AR sebelum dan saat niainya tidak signifikan sedangkan setelah awal Januari pada H1, H2 dan H3 reaksi munculnya Januari Effect sangat terlihat jelas dengan tanda nilai yang signifikan tapi setelah itu nilai kembali menunjukkan tidak signifikan, sehingga disimpulkan bahwa pada tahun 2013-2014 tidak ada January effect. Periode Desember 2014 dengan awal Januari 2015 ditunjukkan dengan nilai signifikansi pada H-1 sehingga indikasi January effect terlihat saat mendekati H0 sedangkan setelah H0 semua nilai tidak signifikan. Periode akhir untuk Desember 2015-Januari 2016 hampir sama dengan periode tahun 2014-2015 kemunculan January effect terlihat sangat dekat yaitu pada H-1 dengan menunjukkan nilai yang signifikan dan bedanya dengan periode sebelumnya setelah H0 ada nilai yang signifikan di hari H7 dan H8, maka disini disimpulkan bahwa Januari effect terjadi tetapi hanya pada periode 2014-2015 dan 2015-2016.

\section{PENUTUP}

Berdasarkan hasil analisis dari uji hipotesis di atas maka peneliti dapat memberikan beberapa kesimpulan bahwa hipotesis pertama memberikan gambaran bahwa pada penelitian periode bulan Desember 2013-Januari 2014 terdapat perbedaan return antara bulan desember dengan bulan Januari, begitupun pada periode berikutnya yaitu Desember 2014-Januari 2015 mendapatkan hasil yang sama dengan periode 
sebelumnya. Hasil yang berbeda diperoleh pada akhir periode penelitian yaitu Desember 2015-Januari 2016 karena tidak menunjukkan adanya perbedaan return pada bulan selain Januari.

Hipotesis kedua berbeda dengan hipotesis pertama karena semua periode menunjukkan hasil yang signifikan walaupun hanya satu hari tapi ada perbedaan abnormal return pada bulan selain Januari karena yang digunakan adalah saham-saham yang termasuk pada indeks islami (JII) sehingga efek Januari ini tidak begitu terlihat jelas karena pada prinsipnya secara syariah harus menjauhi prinsip spekulasi. Penelitian ini sangat sensitif terhadap data dan sampel yang digunakan, karena data yang digunakan bersifat harian dalam jangka waktu yang sangat singkat.

Dalam setiap penelitian pasti ada kekurangan begitupun kelebihannya, berikut beberapa saran yang peneliti sampaikan untuk melengkapi kekurangan pada penelitian ini, antara lain sampel yang digunakan bisa ditambahkan dari indeks yang lain atau bidang industri yang berbeda, jumlah sampel untuk penelitian semakin banyak semakin robust, bisa menggabungkan beberapa event dalam satu penelitian yang memiliki hubungan dan konteks yang berdekatan seperti : week effect, size effect dan sebagainya, data dalam penelitian ini menggunakan adjusted closing price, untuk penelitian lanjutan bisa membandingkan dengan data closing price (yang belum disesuaikan) sehingga bisa melihat perbandingan kedua data tersebut setelah dilakukan analisis, dan waktu event sebelum dan sesudahnya bisa ditambahkan lebih lama dengan tujuan adanya kemungkinan dampak informasi lain yang berpengaruh terhadap event study tersebut.

\section{DAFTAR PUSTAKA}

Asri, M. 2013. Keuangan Keperilakuan. BPFE. Yogyakarta.

Aprilia, Rini. Akbar, Alfian. Dan Wijaya, Hadi. 2013. Analisis January effect Pada Sektor Manufaktur di Bursa Efek Indonesia. E-Jurnal STIE MD Palembang.

Banz, R. 1981. The Relationship Between return and Market Value of Common Stock. Journal of Finance Economic. 9: 3-18.

Bodie, etal. 2011. Investment and Portofolio Management. McGraw-Hill

De Bondt, F. M. Werner dan Thaler, Richard. 1985. Does the stock market overreact?. The Journal of Finance. Vol. XL, No.3. Juli.

Dosinta, Nina F. 2004. Weak Form of Market Efficient Hypothesis: To See the Increase of Efficiency on Two Different Periods. Tesis Magister Akuntansi. FEB UGM: tidak dipublikasikan

Fama, E, F., et al. 1969. The Adjustment Of StockPrices ToNew Information. International Economic Review. Vol. 10, No. 1. Februari

Fama, E. F. 1970. Efficient Capital Markets: A Review of Theory and Empirical Work. The Journal of Finance. 25. 383-417.

Hartini, Titin dan Fitriani, Elvira. 2013. Pengaruh January Effect Terhadap Abnormal Return Pada Saham Sektor Otomotif Yang Terdaftar di BEI. E-Jurnal. STIE MD Palembang.

Hartono. J. 2014. Teori Portofolio dan Analisi Investasi. Edisi kesembilan. BPFE. Yogyakarta.

Haugen, R dan P, Jurion. 1966. The January Effect: Still There After These Years. Financial Analyst Journal, Vol. 52: 27-31

Henke, Harald. 2002. Tax-Loss Selling and Windows-Dressing: An Investigation of The January Effect in Poland department of Economics. Eropa University Viadrina Frankfrut. Germany.

Husnan, Suad. 2009. Teori Portofolio dan Analisis Sekuritas. UPP STIM YKPN. Yogyakarta

Jones, C. P. 2004. Investment: Analysis and Management. John Willey \& Sons. New York. 
Pratomo, Wahyu Agus. 2007. January Effect dan Size Effect pada Bursa Efek Jakarta Periode 1998-2005. Tesis Magister Manajemen UNDIP

Rogalsy, R. J. 1984. New Finding Regarding Day of The Week Returns Over Trading and Non Trading Periods: A Note Journal of Finanance, Desember 1603-1614

Rozzef, M, S dan Kinney, Jr. 1976. Capital Market Seasonality: The Case of Returns. Journal of Financial Economic 3.

Sari, Ratna dan Fitriyani, Indah. 2013. Analisis January Effect Pada Kelompok Saham Indeks LQ-45 di BEI tahun 2009-20011. E-Jurnal Akuntansi. Universitas Udayana 4.2

Sartono. Agus. 1999. Manajemen Keuangan Teori dan Aplikasi. Edisi ketiga. BPFE. Yogyakarta

Wicaksono, Bambang W. 2005. Pengujian Price Reversal Terhadap Saham-Saham di Bursa Efek Jakarta. Tesis Magister Sains Management. FEB UGM: tidak dipublikasikan.

Zaqi, Mochamad. 2006. Reaksi Pasar Modal Terhadap Peristiwa-Peristiwa Ekonomi Dan Peristiwa-Peristiwa Social Politik Dalam Negeri (Studi Pada Saham LQ 45 di BEJ Periode Tahun 1999-2003). Tesis Magister Manajemen. FEB UNDIP 